\title{
5
}

\section{Effects on Soil Fertility and Microbial Populations of Broadcast-Transplanting Rice Seedlings in High Standing-Stubble Under No-Tillage in Paddy Fields}

\author{
Ren Wan-Jun, Huang Yun and Yang Wen-Yu \\ Sichuan Agricultural University, Wenjiang, Sichuan,
} China

\section{Introduction}

No-tillage broadcast-transplanting of rice is a new cultivation technology developed in recent years (Xia, 2003; Liu et al., 2002). Our system involves no-tillage of rice paddies, which leaves high standing stubble, and raising seedlings on dryland beds. Then, we developed the technology of broadcast-transplanting seedlings in the field with high standing-stubble under no-tillage condition (Fig.1 4), which has several advantages such as lower fuel costs, savings in labour and time (yang et al., 2000; Liu, 2006; Ren et al., 2008). The first experiments of broadcast-transplanting of rice began in 1950s, reported by Peiris (1956) in Sri Lanka. In the 1980s, broadcast-transplanting of rice was successfully used in China (Zhang et al., 1993). From the middle and late 1990s, Guangdong province (Liu et al., 2002) and Guangxi province (Jiang et al., 2005) experimented with no-tillage broadcasttransplanting of rice under two rice crops and Sichuan province (Liu and Li, 2002) under single indica rice crop. Compared with conventional tillage broadcast-transplanting, the notillage broadcast-transplanting rice grew slower and had fewer tillers at the early stage (Liu et al., 2002) , as well, root biomass and length were reduced during the seedling standing period (Jiang et al., 2005), but it brought to a higher spike-bearing rate and more grains.

Residue management is an important component of this new rice production system (broadcast-transplanting seedlings into high standing-stubble under no-tillage condition). In addition to the 20 to $50 \mathrm{~cm}$ of high stubble left upon harvest of the previous crops (wheat or rape) harvested, the farmer is encouraged to return the harvested stubble from previous crops to the field (yang et al., 2000; Ren et al., 2003). This practice increases the soil fertility: soil organic matter, total $\mathrm{N}$ and $\mathrm{K}$, and available $\mathrm{N}$ and $\mathrm{K}$ concentrations were higher than those of conventional tillage paddy fields, either with conventional rice transplanting or broadcast-transplanting rice in one study (Ren et al., 2007). This promising result needs to be verified in other paddy fields, to determine the effects of broadcast-transplanting seedlings into no-tillage fields with high standing-stubble on soil fertility and microbial populations in paddy field. The objectives of this study were to clarify the influence of the new technology on soil fertility and microbial populations of paddy field, and to provide a scientific basis 
and give some evidence in the introduction - what type of yields can be achieved with the broadcast-transplanting method in a no-tillage field?

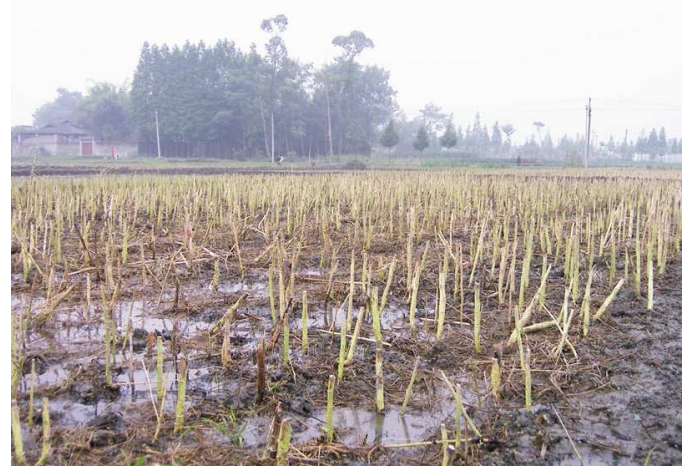

Fig. 1. Field covered with high standing-stubble from the previous rape crop

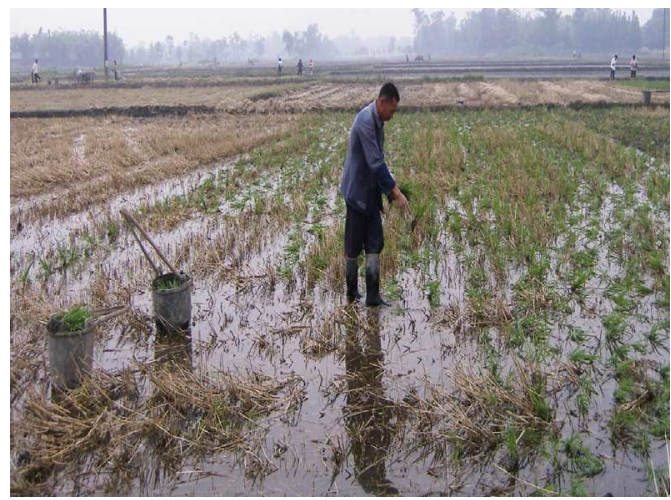

Fig. 2. Broadcasting rice seedlings into high standing-stubble

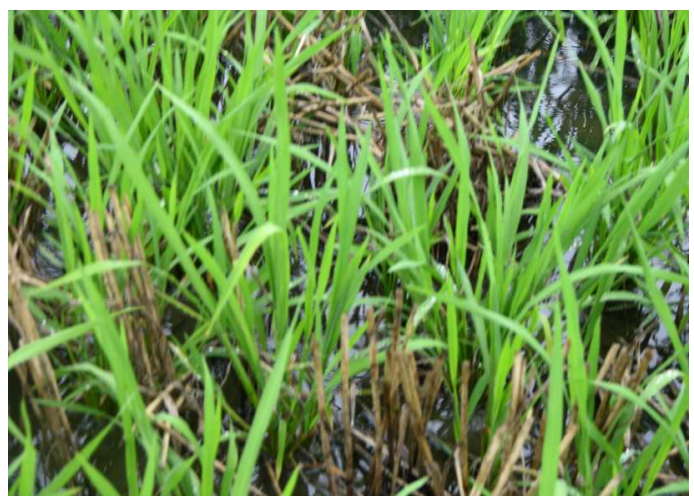

Fig. 3. Early growth stage of rice seedlings 


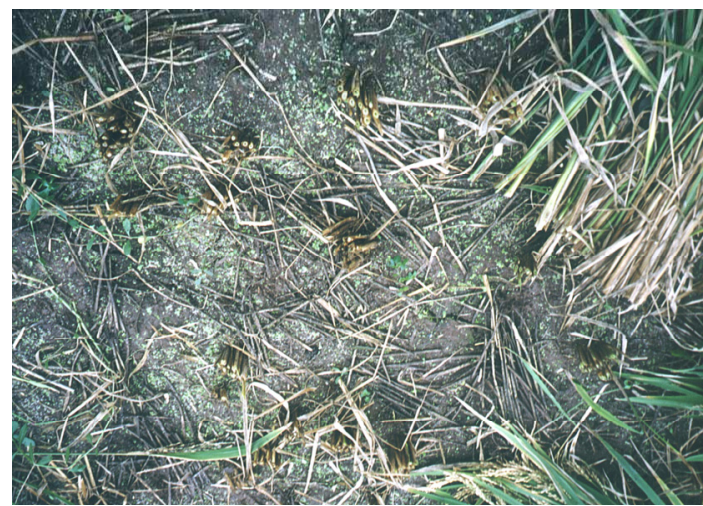

Fig. 4. Straw decay and soil surface conditions after rice harvest

\section{Materials and methods}

\subsection{Plant material and condition}

Ya' an experiment: The hybrid rice combinations Gangyou22, Ilyou162 and Kyou047 were the cultivars used in this study. The experiments were conducted in the paddy at Daxing town of Ya' an city, Sichuan province, China (lat. $29^{\circ} 59 \mathrm{~N}$, long. $102^{\circ} 59 \mathrm{E}$ ) in 2003. The experiment was on a sandy-loam soil with the following chemical properties: organic matter $23.66 \mathrm{~g} \mathrm{~kg}^{-1}$; total N $1.422 \mathrm{~g} \mathrm{~kg}^{-1}$, alkali hydrolysable $\mathrm{N} 109.36 \mathrm{mg} \mathrm{kg}^{-1}$; total P $0.458 \mathrm{~g} \mathrm{~kg}^{-1}$, available P $12.01 \mathrm{mg} \mathrm{kg}^{-1}$; total K $11.66 \mathrm{~g} \mathrm{~kg}^{-1}$, available K $30.22 \mathrm{mg} \mathrm{kg}^{-1}$. Previous crop was rape.

Pixian experiment: The hybrid rice combination Ilyou21 were used as plant materials in this study. The experiment was conducted in the paddy at Gucheng town of Chengdu city, Sichuan province, China (lat. $30^{\circ} 93 \mathrm{~N}$, long. $103^{\circ} 91 \mathrm{E}$ ) in 2005 . The experiment was on a fluviatile loamsandy soil, and its chemical properties were as follows: organic matter, $18.73 \mathrm{~g} \mathrm{~kg}^{-1}$; total $\mathrm{N}, 1.18 \mathrm{~g} \mathrm{~kg}^{-1}$, alkali hydrolysable $\mathrm{N}, 78.26 \mathrm{mg} \mathrm{kg}^{-1}$; total $\mathrm{P} 0.21 \mathrm{~g} \mathrm{~kg}^{-1}$, available $\mathrm{P}, 43.53 \mathrm{mg} \mathrm{kg}^{-1}$; total $\mathrm{K}, 22.73 \mathrm{~g} \mathrm{~kg}^{-1}$, available $\mathrm{K}, 42.21 \mathrm{mg} \mathrm{kg}^{-1}$. Previous crop was wheat.

\subsection{Experimental treatment and cultivation management}

$\mathrm{Ya}^{\prime}$ an experiment: The experiment was laid out in a split plot design with tillage and cultivation methods in the main plots and hybrid combination in the sub-plots with three replicates. Plot area was $15.84 \mathrm{~m}^{2}$. In the tillage and cultivation methods, there were three levels, including as conventional tillage and transplanting (CTT), conventional tillage and broadcast-transplanting of seedlings (CTB) and broadcast-transplanting of seedlings in the field with high standing-stubble under no-tillage condition (BSNT). The hybrid combination tested were Gangyou22, Ilyou162 and Kyou047. The seedlings of CTT were raised on wet land and seeded at a rate of $30 \mathrm{~g} \mathrm{~m}^{-2}$; those of CTB and BSNT were raised on plastic trays with 428 holes and each hole was seeded about 2 seeds. Seeds were sown on March 30, then transplanted on May 9. When previous rape was harvested, $50 \mathrm{~cm}$ of stubble was left in the 
field. The soil was plowed and plugged after removing the rape stubble in tillage treatments; for no-tillage treatments, a herbicide was used 5 days after harvesting rape. Then paddies were irrigated to reach soil water saturation prior to broadcast-transplanting. Fertilizer inputs as a basal dressing were at the following rates: $90 \mathrm{~kg} \mathrm{P}_{2} \mathrm{O}_{5} \mathrm{ha}^{-1}$ as superphosphate, $45 \mathrm{~kg} \mathrm{~K}_{2} \mathrm{O}$ ha-1 as $\mathrm{KCl}$ and $105 \mathrm{~kg} \mathrm{~N}^{-1}$ as urea. Additional $45 \mathrm{~kg} \mathrm{~N} \mathrm{ha}^{-1}$ was broadcasted at the tillering stage and $45 \mathrm{~kg} \mathrm{~K}_{2} \mathrm{O} \mathrm{ha}^{-1}$ at the booting stage. The transplanting density was $30 \times 10^{4}$ hills ha-1. Irrigation water was kept at $1-5 \mathrm{~cm}$ depth for 1 week following transplanting to aid in seedling establishment. Pests were controlled according to the standard recommendation and other rice management was similar as that in the paddy field (Ren et al., 2003).

Pixian experiment: The experiment was carried out in a randomized plot design with four treatments: No-tillage+Straw $(\mathrm{NT}+\mathrm{S})$, No-tillage $(\mathrm{NT})$, Tillage+Straw $(\mathrm{T}+\mathrm{S})$ and Tillage $(\mathrm{T})$. There were three replicates of each treatment, in plots of $30 \mathrm{~m}^{2}$. Ridges were built between plots to avoid fertilizer and water movement to adjacent plots. The $+S$ treatment involved returning straw to soil that was removed when the previous wheat crop was harvested (leaving $25 \mathrm{~cm}$ of stubble in the field). After rice seedlings was survived, the straw was returned and scattered evenly in the plots. Returned straw provided an organic residue input of about 5-6 t ha-1. In the NT+S treatment, straw was left on the soil surface, but the $\mathrm{T}+\mathrm{S}$ treatment involved cultivating and mixing straw with soil. For tillage treatments, we plowed and plugged the soil after removing the wheat stubble. In the no-tillage treatments, a herbicide was used 5 days after harvesting wheat. Then we irrigated the paddy until it reached soil water saturation prior to broadcast-transplanting. Seeds were sown on March 20, then transplanted on May 23. Fertilizer inputs as a basal dressing were at a rate of $75 \mathrm{~kg}$ $\mathrm{P}_{2} \mathrm{O}_{5}$ ha $^{-1}$ as superphosphate, $75 \mathrm{~kg} \mathrm{~K}_{2} \mathrm{O}$ ha-1 as $\mathrm{KCl}$ and $105 \mathrm{~kg} \mathrm{~N}^{-1}$ as urea. Additional 30 $\mathrm{kg} \mathrm{N}$ ha-1 was broadcasted at the tillering stage and $75 \mathrm{~kg} \mathrm{~K}_{2} \mathrm{O}$ ha $^{-1}$ and $15 \mathrm{~kg} \mathrm{~N}^{-1}$ at the booting stage. The transplanting density was $25.5 \times 10^{4}$ hills ha-1. Irrigation water was kept at 1-5 cm depth for 1 week following transplanting to aid in seedling establishment. Pests were controlled according to the standard recommendation and other rice management was similar as that in the paddy field (Ren et al., 2003).

\subsection{Soil and plant analysis}

\subsubsection{Soil fertility}

Samples for nutrient measurement were sampled randomly with soil drill $(25 \mathrm{~mm}$ in diameter).Five cores were taken after rice harvest from the 0-10 $\mathrm{cm}$ (upper layer) and 10$20 \mathrm{~cm}$ (deep layer) from each plot and pooled together. Large pieces of plant and animal resideues, gravel, etc., were removed by sieving soil through a 2-mm mesh, mixing and a subsample was taken for analysis. Concentrations of soil organic matter, total N, P and K, alkali hydrolysable $\mathrm{N}$, available $\mathrm{P}$ and $\mathrm{K}$ were tested by the methods described by Lu (2000).

\subsubsection{Soil microorganism enumeration}

Soil samples for microbiological assessment and cellulose decomposition intensity were collected from the Pixian experiment only at the tillering stage, elongation stage, booting stage 
and maturity stage of rice from the 0-10 cm (upper layer) and 10-20 $\mathrm{cm}$ (deep layer) from each plot and pooled together. Samples were cooled with ice packs in the field immediately after collection, and were stored at $4^{\circ} \mathrm{C}$ for later analysis. Microbial communities were enumerated using the dilution plate method. Bacteria was isolated by BF medium, fungi was cultured by Martin agar medium and actinomyces were determined by modified Goss I medium (Department of Microbiology, 1985). Cellulose decomposition intensity was tested by the method of burying fabric into situ in the laboratory (Department of Microbiology, 1985).

\subsubsection{Rice development and yield}

Sixty (60) hill plants from each plot were investigated to study panicle development. Five (5) hills from each plot were harvested at maturity to estimate the yield components. The grain filling percentage was determined according to Zhu et al (1995). All plants from each plot were harvested at maturity for the determination of grain yield.

\subsection{Statistical method}

Statistical analyses were made by Office Excel 2003 and the SAS-Stat package (SAS Institute Inc. 1996). The Duncan test and 1east significant difference test at the $90 \%$ and $95 \%$ confidence levels were used to compare treatment means.

\section{Results}

\subsection{Effects on soil fertility of tillage and residue management in a system with broadcast-transplanting of rice seedlings}

Soil fertility was increased when rice seedlings were broadcast-transplanted among high standing-stubble under no-tillage condition (BSNT), as the organic matter, total N and K, and available $\mathrm{N}$ and $\mathrm{K}$ concentrations were higher than those of conventional tillage systems with conventional transplanting or broadcast-transplanting (Table1).

\begin{tabular}{cccccccc}
\hline Treatment & $\begin{array}{c}\text { Organic } \\
\text { matter } \\
\left(\mathrm{g} \mathrm{kg}^{-1}\right)\end{array}$ & $\begin{array}{c}\text { Total N } \\
\left(\mathrm{g} \cdot \mathrm{kg}^{-1}\right)\end{array}$ & $\begin{array}{c}\text { Total P } \\
\left.(\mathrm{g} \mathrm{kg})^{-1}\right)\end{array}$ & $\begin{array}{c}\text { Total K } \\
\left(\mathrm{g} \mathrm{kg} \mathrm{kg}^{-1}\right)\end{array}$ & $\begin{array}{c}\text { Alkali } \\
\text { hydrolysable } \\
\left(\mathrm{mg} \cdot \mathrm{kg}^{-1}\right)\end{array}$ & $\begin{array}{c}\text { Available } \\
\left(\mathrm{mg} \cdot \mathrm{kg}^{-1}\right)\end{array}$ & $\begin{array}{c}\text { Available K } \\
\left(\mathrm{mg} \cdot \mathrm{kg}^{-1}\right)\end{array}$ \\
\hline CTT & 23.42 & 1.444 & 0.604 & 14.24 & 109.89 & 15.88 & 33.45 \\
CTB & 23.31 & 1.506 & 0.583 & 12.55 & 105.29 & 13.66 & 36.59 \\
BSNT & 30.04 & 2.375 & 0.524 & 15.18 & 131.72 & 14.25 & 61.93 \\
$\begin{array}{c}\text { Initial soil } \\
\text { fertility }\end{array}$ & 23.66 & 1.422 & 0.458 & 11.66 & 109.36 & 12.01 & 30.22 \\
\hline
\end{tabular}

CTT: conventional tillage and conventional transplanting; CTB: conventional tillage and broadcasttransplanting of seedlings; BSNT : broadcast-transplanting of seedlings in the field with high standingstubble under no-tillage condition.

Table 1. Effects of different tillage and transplanting methods on soil fertility $(0-20 \mathrm{~cm}$ depth) in paddy field. The experiment was conducted near Ya' an city, Sichuan province, China in 2003. 
As shown in Table 2, in the upper $0-10 \mathrm{~cm}$ soil layer, the organic matter content for 'notillage + returning straw' treatment was $5.33,2.79$ and $5.37 \mathrm{~g} \mathrm{~kg}^{-1}$ higher than that for 'notillage', 'tillage + returning straw' and 'tillage' treatment, respectively. However, in the deep 10-20 cm layer, content of organic matter in 'tillage + returning straw' and 'tillage' treatments were higher than others. Since residues are mostly left on the surface in the notillage treatment, there organic matter accumulation was found in the surface soil, whereas a tilled soil had organic matter incorporated into the deeper soil layer. The maximum difference of two soil layers was noted for the 'no-tillage + returning straw' treatment, and there was little difference in soil organic matter in the 'no-tillage' treatment, and 'tillage' treatment without the extra straw residue input.

In upper soil layer, total and available $\mathrm{N}, \mathrm{P}$ and $\mathrm{K}$ concentrations were greatest in the "notillage + returning straw' treatment, those in the 'no-tillage' treatment and 'tillage + returning straw' treatment followed, and those in the 'tillage' treatment were the lowest. In the deep layer, the soil fertility indicators for 'tillage + returning straw' treatment were greater than those for other treatments. At the same time, the difference of nutrient status between two soil layers was the maximum for 'no-tillage + returning straw' treatment, therefore, the 'no-tillage + returning straw' treatment enriched soil fertility in the surface soil layer.

\begin{tabular}{|c|c|c|c|c|c|c|c|c|}
\hline $\begin{array}{c}\text { Soil } \\
\text { layer }\end{array}$ & Treatment & $\begin{array}{l}\text { Organic } \\
\text { matter } \\
\left(\mathrm{g} \cdot \mathrm{kg}^{-1}\right)\end{array}$ & $\begin{array}{l}\text { Total N } \\
\left(\mathrm{g} \cdot \mathrm{kg}^{-1}\right)\end{array}$ & $\begin{array}{l}\text { Total P } \\
\left(g \cdot \mathrm{kg}^{-1}\right)\end{array}$ & $\begin{array}{l}\text { Total K } \\
\left(\mathrm{g} \cdot \mathrm{kg}^{-1}\right)\end{array}$ & $\begin{array}{c}\text { Alkali } \\
\text { hydrolysable } \\
\mathrm{N} \\
\left(\mathrm{mg} \cdot \mathrm{kg}^{-1}\right)\end{array}$ & $\begin{array}{c}\text { Available P } \\
\left(\mathrm{mg} \cdot \mathrm{kg}^{-1}\right)\end{array}$ & $\begin{array}{c}\text { Available K } \\
\left(\mathrm{mg} \cdot \mathrm{kg}^{-1}\right)\end{array}$ \\
\hline \multirow{4}{*}{$\begin{array}{l}\text { Upper } \\
\text { layer }\end{array}$} & $\mathrm{NT}+\mathrm{S}$ & $30.02 a$ & $1.67 \mathrm{a}$ & $0.260 \mathrm{a}$ & $29.114 a$ & $120.250 \mathrm{a}$ & $82.593 a$ & $81.063 a$ \\
\hline & NT & $24.69 b$ & $1.62 \mathrm{ab}$ & $0.255 a$ & $26.556 a$ & $113.436 b$ & $70.739 b$ & 71.095ab \\
\hline & $\mathrm{T}+\mathrm{S}$ & $27.23 \mathrm{ab}$ & $1.59 \mathrm{~b}$ & $0.254 a$ & $22.900 \mathrm{~b}$ & $110.966 c$ & $69.013 b c$ & $64.718 \mathrm{ab}$ \\
\hline & $\mathrm{T}$ & $24.65 b$ & $1.56 \mathrm{~b}$ & $0.244 b$ & $21.920 \mathrm{c}$ & $101.778 d$ & $64.001 \mathrm{c}$ & $60.497 b$ \\
\hline \multirow{4}{*}{$\begin{array}{l}\text { Deep } \\
\text { layer }\end{array}$} & $\mathrm{NT}+\mathrm{S}$ & $20.69 a$ & $1.35 b$ & $0.223 a$ & $11.255 b$ & $85.162 a$ & $40.305 a$ & $48.983 a$ \\
\hline & NT & $18.12 b$ & $1.34 b$ & $0.221 a$ & $10.241 b$ & $84.572 \mathrm{a}$ & $40.622 a$ & 46.781a \\
\hline & $\mathrm{T}+\mathrm{S}$ & $22.20 \mathrm{a}$ & $1.42 \mathrm{a}$ & $0.224 a$ & $18.784 a$ & $89.686 a$ & $42.890 \mathrm{a}$ & $54.674 \mathrm{a}$ \\
\hline & $\mathrm{T}$ & $22.20 \mathrm{a}$ & $1.40 \mathrm{ab}$ & $0.226 a$ & $16.345 a$ & $87.918 a$ & $40.755 a$ & $51.640 a$ \\
\hline
\end{tabular}

NT+S: No-tillage+Straw; NT: No-tillage; T+S: Tillage+Straw; T: Tillage. Values followed by different small letters meant significant difference at 0.05 level, respectively (LSD test).

Table 2. Effect of different tillage methods on soil fertility in paddy field with broadcasttransplanting of rice. The upper soil layer was $0-10 \mathrm{~cm}$ depth and the lower soil layer was 10-20 cm depth. The experiment was conducted at Pixian near Chengdu city, Sichuan province, China in 2005.

\subsection{Effects on soil microorganisms of tillage and residue management in a system with broadcast-transplanting of rice seedlings}

\subsubsection{Bacterial numbers}

The average numbers of soil bacteria under different treatments are given in Table 3 . The results showed that soil bacterial numbers for 'returning straw to soil' treatments were 
higher than that for 'no returning straw' treatments, and those in upper soil layer were higher than in deep layers too. In upper soil layer, the highest soil bacteria' numbers appeared in the 'no-tillage + returning straw' treatment at five growth stages, and the lowest bacteria' numbers were in the soil under 'tillage'. Bacterial numbers for 'no-tillage + returning straw' treatment were $15.86 \%, 14.0 \%, 2.53 \%$ and $40.44 \%$ higher than that for 'notillage', and $22.62 \%, 13.25 \%, 6.32 \%$ and $29.05 \%$ higher than that for 'tillage + returning straw' treatment at the tillering stage, elongation stage, booting stage and maturity stage of rice, respectively. In the deep soil layer, bacterial numbers appeared lower at tillering stage, and increased during elongation to booting stage, reaching a maximum value at rice booting and declined thereafter. In this soil layer, the highest bacterial numbers appeared in the 'tillage + returning straw' treatment, and the lowest bacteria' numbers were in the soil treated with 'tillage', too.

\subsubsection{Fungal numbers}

The data in Table 3 showed that fungal populations assessed by direct counting were lower than the other microbial groups. Fungal numbers increased during the rice growing season. Soil fungi were more abundant in the upper soil layer than in the deep layer, and greater in 'returning straw to soil' treatments than that for 'no returning straw' treatments. In the upper soil layer, fungal numbers were the highest in the 'no-tillage + returning straw' treatment, followed by the 'no-tillage' treatment, and the lowest fungal numbers were in the soil treated with 'tillage'. In deep soil layer, the order of fungal numbers in all treatments was 'tillage + returning straw'>'no-tillage + returning straw' >'no-tillage'> 'tillage'.

\begin{tabular}{|c|c|c|c|c|c|c|c|c|c|c|c|c|c|}
\hline \multirow{2}{*}{$\begin{array}{l}\text { Soil } \\
\text { layer }\end{array}$} & \multirow{2}{*}{$\begin{array}{l}\text { Trea- } \\
\text { tment }\end{array}$} & \multicolumn{4}{|c|}{ Bacteria $\left(\times 10^{3} \mathrm{CFU} \cdot \mathrm{g}^{-1}\right)$} & \multicolumn{4}{|c|}{ Fungi $\left(\times 10^{3} \mathrm{CFU} \cdot \mathrm{g}^{-1}\right)$} & \multicolumn{4}{|c|}{ Actinomyce $\left(\times 10^{3} \mathrm{CFU} \cdot \mathrm{g}^{-1}\right)$} \\
\hline & & $\begin{array}{l}\text { Tille- } \\
\text { ring }\end{array}$ & $\begin{array}{c}\text { Elonga- } \\
\text { tion }\end{array}$ & $\begin{array}{c}\text { Booti- } \\
\text { ng }\end{array}$ & $\begin{array}{l}\text { Matu- } \\
\text { rity }\end{array}$ & $\begin{array}{l}\text { Tille- } \\
\text { ring }\end{array}$ & $\begin{array}{c}\text { Elonga- } \\
\text { tion }\end{array}$ & $\begin{array}{c}\text { Booti- } \\
\text { ng }\end{array}$ & $\begin{array}{c}\text {-Matu- } \\
\text { rity }\end{array}$ & $\begin{array}{c}\text { Tilleri- } \\
\text { ng }\end{array}$ & $\begin{array}{c}\text { Elonga- } \\
\text { tion }\end{array}$ & $\begin{array}{c}\text { Booti- } \\
\text { ng }\end{array}$ & $\begin{array}{c}\text { Matu- } \\
\text { rity }\end{array}$ \\
\hline \multirow{4}{*}{$\begin{array}{l}\text { Upper } \\
\text { layer }\end{array}$} & $\mathrm{NT}+\mathrm{S}$ & 168 & 171 & 202 & 191 & 2.6 & 2.89 & 5.16 & 6.23 & 130 & 108 & 155 & 189 \\
\hline & NT & 145 & 150 & 197 & 136 & 1.6 & 2.64 & 4.35 & 5.29 & 135 & 90 & 120 & 134 \\
\hline & $\mathrm{T}+\mathrm{S}$ & 137 & 151 & 190 & 148 & 1.2 & 1.7 & 3.38 & 4.82 & 134 & 72 & 104 & 108 \\
\hline & $\mathrm{T}$ & 85 & 103 & 157 & 94 & 0.8 & 1.44 & 2.56 & 4.45 & 104 & 44 & 96 & 97 \\
\hline \multirow{4}{*}{$\begin{array}{l}\text { Deep } \\
\text { layer }\end{array}$} & $\mathrm{NT}+\mathrm{S}$ & 72 & 89 & 132 & 94 & 1 & 1.1 & 2.7 & 3.1 & 50 & 30 & 67 & 57 \\
\hline & NT & 75 & 78 & 138 & 98 & 0.5 & 0.7 & 2.3 & 2.2 & 46 & 27 & 59 & 48 \\
\hline & $\mathrm{T}+\mathrm{S}$ & 83 & 99 & 143 & 100 & 1.1 & 1.5 & 2.9 & 3.9 & 64 & 41 & 77 & 66 \\
\hline & $\mathrm{T}$ & 64 & 70 & 109 & 63 & 0.3 & 0.5 & 1.5 & 2.7 & 32 & 12 & 48 & 39 \\
\hline
\end{tabular}

NT+S: No-tillage+Straw; NT: No-tillage; T+S: Tillage+Straw; T: Tillage.

Table 3. Effect of different tillage methods on soil microbial population in paddy field with broadcast-transplanting of rice. The upper soil layer was 0-10 $\mathrm{cm}$ depth and the lower soil layer was 10-20 cm depth. The experiment was conducted at Pixian near Chengdu city, Sichuan province, China in 2005. 


\subsubsection{Actinomycete numbers}

Actinomycete numbers are affected by gas permeability of soil because that this microbial group are facultative aerobes. The data in Table 3 showed that actinomycete numbers were the lowest at elongation stage, increasing thereafter and reaching a peak at booting stage (deep soil layer) or maturity stage (upper soil layer) of rice. In upper soil layer, 'no-tillage + returning straw' treatment appeared to possessaerobic microsites, therefore, it had the highest actinomycete numbers except at tillering stage. The lowest actinomycete numbers were in the 'tillage' treatment, presumably because conditions were not favorable for aerobic microorganisms, particularly in the deep soil layer, which had fewer actinomycetes than in the upper soil layer. In deep soil layer, actinomycetes abundance in four treatments followed the order 'tillage + returning straw'>'no-tillage + returning straw' >'no-tillage'> 'tillage'.

\subsection{Effects on cellulose decomposition intensity of tillage and residue management in a system with broadcast-transplanting of rice seedlings}

The cellulose decomposition intensity under as affected by residue management and tillage at the Pixian experiment was shown in Fig. 5. The highest cellulose decomposition intensity appeared at the tillering stage and booting stage during different growth periods of rice. At the same time, cellulose decomposition intensity in 'returning straw to soil' treatments were higher than 'no returning straw' treatments. In upper soil layer, cellulose decomposition intensity in 'no-tillage + returning straw' treatment was always higher than that in other treatments. At the tillering stage of rice, cellulose decomposition intensity in 'no-tillage + returning straw' treatment was $28.20 \%, 39.76 \%$ and $52.93 \%$ higher than that in 'tillage + returning straw', 'no-tillage' and 'tillage' treatment; furthermore, 25.51\%, 46.27\% and 91.62\% higher at elongation stage of rice; $38.76 \%, 68.60 \%$ and $79.71 \%$ higher at booting stage of rice; and $26.44 \%, 79.01 \%$ and $98.15 \%$ higher at maturity stage of rice, respectively. There was little difference between 'no-tillage' and 'tillage' treatment. In the deeper soil layer, the highest cellulose decomposition intensity was the treatment of 'tillage + returning straw', probably due to incorporation of straw into the deep soil layer, which enhanced the activity of cellulose decomposing bacteria.

\subsection{Correlation between soil microorganisms and soil fertility in paddy field with broadcast-transplanting of rice seedlings in no-tillage and conventional tillage plots}

The relationship between soil microorganisms and soil fertility at the Pixian experiment was analyzed (Table 4). There were significant positive correlations between soil bacterial numbers and the soil organic matter, total $\mathrm{N}$, total $\mathrm{P}$, total $\mathrm{K}$, alkali hydrolysable $\mathrm{N}$ and available $\mathrm{P}$ concentrations. In contrast, soil fungi numbers were not correlated with soil fertility indicators. There were significant positive correlations between soil actinomycete numbers and the soil organic matter, total $\mathrm{N}$, total $\mathrm{P}$, total $\mathrm{K}$, alkali hydrolysable $\mathrm{N}$, available $\mathrm{P}$ and $\mathrm{K}$ concentrations. The cellulose decomposition intensity was significantly and positively correlated with the soil fertility indicators, which indicated that high cellulose decomposition intensity was related to improved soil nutrient status. 

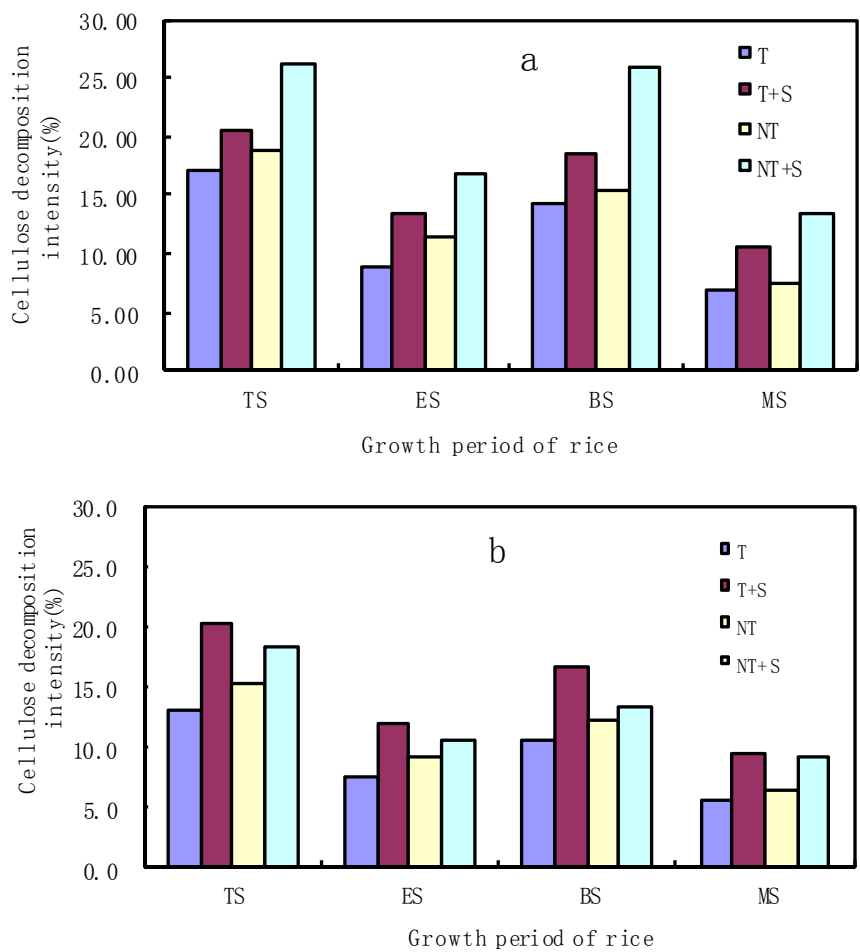

TS: Tillering stage; ES: Elongation stage; BS: Booting stage; MS: Maturity stage. NT+S: No-tillage+Straw; NT: No-tillage; $T+S$ : Tillage+Straw; T: Tillage.

Fig. 5. Effect of different tillage and residue management methods on cellulose decomposition intensity in paddy field with broadcast-transplanting of rice. Results are for (a) the upper soil layer, 0-10 cm depth and (b) the lower soil layer, 10-20 cm depth. The experiment was conducted at Pixian near Chengdu city, Sichuan province, China in 2005.

\begin{tabular}{|c|c|c|c|c|c|c|c|}
\hline Factor & Total K & Total N & Total P & $\begin{array}{c}\text { Available } \\
\text { K }\end{array}$ & $\begin{array}{c}\text { Alkali } \\
\text { hydrolysable } \\
\mathrm{N}\end{array}$ & $\begin{array}{c}\text { Available } \\
\text { P }\end{array}$ & $\begin{array}{c}\text { Organic } \\
\text { matter }\end{array}$ \\
\hline Bacteria & $0.5858^{*}$ & $0.6447^{*}$ & $0.7107^{* *}$ & 0.5253 & $0.6610^{*}$ & $0.5625^{*}$ & $0.7139 * *$ \\
\hline Fungi & 0.3956 & -0.0925 & 0.5613 & -0.6073 & -0.4090 & -0.5324 & 0.0360 \\
\hline Actinomycete & $0.8217^{* *}$ & $0.8310^{* *}$ & $0.8393^{* *}$ & $0.7307^{* *}$ & $0.8404^{* *}$ & $0.7552^{* *}$ & $0.6110^{*}$ \\
\hline $\begin{array}{l}\text { Cellulose } \\
\text { decomposition } \\
\text { intensity }\end{array}$ & $0.6781^{*}$ & $0.7854^{* *}$ & $0.8848^{* *}$ & $0.8535^{* *}$ & $0.8339 * *$ & $0.8623^{* *}$ & $0.8818^{* *}$ \\
\hline
\end{tabular}

All the data was used for correlation analysis. ${ }^{*} P<0.05 ;{ }^{* *} P<0.01$.

Table 4. Correlation ( $\mathrm{r}$ values) between soil microorganisms and soil fertility in paddy field with broadcast-transplanting of rice seedlings in no-tillage and conventional tillage plots. The experiment was conducted at Pixian near Chengdu city, Sichuan province, China in 2005. 


\subsection{Effects on rice yield and its components in paddy field with contrasting tillage and transplanting methods, including broadcast-transplanting of rice seedlings}

Analysis of variance showed that the main effect of yield by tillage and transplanting methods was significant at $P<0.1\left(F_{\mathrm{A}}=3.17, F_{0.05}=3.63, P=0.069\right)$ and yield followed the order: CTT $>$ BSNT $>$ CTB (Table 1$)$. There was no difference due to the hybrid grown $\left(F_{\mathrm{B}}=0.36\right.$, $\left.F_{0.05}=3.63\right)$ and interaction of the hybrid by tillage and transplanting method $\left(F_{\mathrm{A} \times \mathrm{B}}=1.99\right.$, $\left.F_{0.05}=3.01\right)$ was not significant. Among three tillage and transplanting methods,

\begin{tabular}{|c|c|c|c|c|c|c|c|}
\hline \multicolumn{2}{|c|}{ Treatment } & $\begin{array}{c}\text { Effective } \\
\text { panicle } \\
\left(\text { No. } \mathrm{m}^{-2}\right)\end{array}$ & $\begin{array}{l}\text { Spikelet } \\
(\text { No. ear-1) }\end{array}$ & $\begin{array}{c}\text { Seed- } \\
\text { setting } \\
\text { rate } \\
(\%)\end{array}$ & $\begin{array}{c}\text { Filled grain } \\
\text { percentage } \\
(\%)\end{array}$ & $\begin{array}{c}1000- \\
\text { grain } \\
\text { weight } \\
(\mathrm{g})\end{array}$ & $\begin{array}{l}\text { Yields } \\
(\text { kg.m-2) }\end{array}$ \\
\hline \multirow{3}{*}{ CTT } & Gangyou22 & $175.2 \mathrm{~b}$ & $167.6 \mathrm{a}$ & $87.69 \mathrm{a}$ & 77.67 a & $26.31 \mathrm{a}$ & $0.683 \mathrm{a}$ \\
\hline & IIyou162 & $189.0 \mathrm{~b}$ & $179.4 \mathrm{a}$ & $77.23 \mathrm{~b}$ & $73.71 \mathrm{a}$ & $26.65 \mathrm{a}$ & $0.689 \mathrm{a}$ \\
\hline & Kyou047 & $214.7 \mathrm{a}$ & $140.1 \mathrm{~b}$ & $89.20 \mathrm{a}$ & 77.93 a & $26.46 \mathrm{a}$ & $0.697 \mathrm{a}$ \\
\hline \multicolumn{2}{|c|}{ Mean } & $193.0 \mathrm{ab}$ & $162.4 \mathrm{~b}$ & $84.71 \mathrm{a}$ & $76.44 \mathrm{ab}$ & $26.47 \mathrm{a}$ & $0.690 \mathrm{a}$ \\
\hline \multirow{3}{*}{ СТВ } & Gangyou22 & $177.4 \mathrm{~b}$ & $155.5 \mathrm{a}$ & $82.16 \mathrm{a}$ & $73.56 \mathrm{~b}$ & $25.57 \mathrm{a}$ & $0.650 \mathrm{ab}$ \\
\hline & IIyou162 & $184.6 \mathrm{~b}$ & $172.4 \mathrm{a}$ & $72.90 \mathrm{~b}$ & $72.20 \mathrm{~b}$ & $25.49 \mathrm{a}$ & $0.596 \mathrm{~b}$ \\
\hline & Kyou047 & $227.0 \mathrm{a}$ & $131.8 \mathrm{~b}$ & $80.90 \mathrm{a}$ & $78.47 \mathrm{a}$ & $25.68 \mathrm{a}$ & $0.676 \mathrm{a}$ \\
\hline \multicolumn{2}{|c|}{ Mean } & $196.3 \mathrm{a}$ & $153.2 \mathrm{~b}$ & $78.65 \mathrm{~b}$ & $74.74 \mathrm{~b}$ & $25.58 \mathrm{~b}$ & $0.641 \mathrm{~b}$ \\
\hline \multirow{3}{*}{ BSNT } & Gangyou22 & $172.7 \mathrm{~b}$ & $187.6 \mathrm{a}$ & $82.35 \mathrm{~b}$ & $77.58 \mathrm{ab}$ & $26.77 \mathrm{a}$ & $0.676 \mathrm{a}$ \\
\hline & IIyou162 & $172.0 \mathrm{~b}$ & $201.0 \mathrm{a}$ & $79.48 \mathrm{~b}$ & $75.29 \mathrm{~b}$ & $26.98 \mathrm{a}$ & $0.677 \mathrm{a}$ \\
\hline & Kyou047 & $205.5 \mathrm{a}$ & $141.1 \mathrm{~b}$ & $87.12 \mathrm{a}$ & $80.57 \mathrm{a}$ & $26.60 \mathrm{a}$ & $0.628 \mathrm{a}$ \\
\hline \multicolumn{2}{|c|}{ Mean } & $183.4 \mathrm{~b}$ & 176.6 Aa & $82.99 \mathrm{a}$ & $77.81 \mathrm{a}$ & $26.78 \mathrm{a}$ & $0.660 \mathrm{ab}$ \\
\hline
\end{tabular}

CTT: conventional tillage and transplanting; CTB: conventional tillage and broadcasting seedlings; BSNT:broadcasting seedlings in the field with high standing-stubbles under no-tillage condition.

Table 5. Effect on rice yield and yield components of rice of different tillage and transplantingmethods, and hybrid types, in a paddy field. The experiment was conducted near Ya' an city, Sichuan province, China in 2003.

effective panicles were affected as follows: $\mathrm{CTB}>\mathrm{CTT}>\mathrm{BSNT}$, and there were significantly more effective panicles in CTB than in BSNT $\left(F_{\mathrm{A}}=4.06, F_{0.05}=3.63, F_{0.01}=6.23\right)$. Under three tillage and transplanting methods, effective panicles of Kyou047 were the highest among three combinations. There were significant differences in the number of spikelets among different tillage and transplanting methods and between hybrids $\left(F_{\mathrm{A}}=12.30, F_{\mathrm{B}}=50.68\right.$, $F_{0.01}=6.23$ ), and BSNT had $8.74 \%$ and $15.27 \%$ more spikelets than CTT and CTB, respectively. 
Among three combinations, Ilyou162 had the greatest number of spikelets, and Kyou047 had the fewest. СТВ had the lowest seed-setting rate, at $6.06 \%$ and $4.34 \%$ less seed-setting rate than CTT and BSNT, and this was significant $(P<0.05)$. Among three hybrids, Ilyou162 had the lowest seed-setting rate. BSNT had the highest percentage of filled grain, which was significantly $(P<0.05)$ higher than that of CTB; filled grain percentage of Kyou047 was also significantly $(P<0.05)$ higher than Gangyou22 and Ilyou162. The 1000-grain-weight values were ranked BSNT>CTT>CTB, and those of BSNT and CTT were $1.20 \mathrm{~g}$ and $0.89 \mathrm{~g}$ higher than CTB, but no significant difference due to or hybrid combinations was detected for 1000grain-weight.

\section{Discussion}

Our results showed that the method of broadcast-transplanting seedlings in the field with high standing-stubble and extra straw residues under no-tillage condition ("no-tillage + returning straw' treatment) promoted soil microbial populations at the surface soil layer because it returned about 5-6 t ha ${ }^{-1}$ of straw to soil. Larger soil microbial populations are attributed to a more favorable soil ecological environment, with good conditions of water, nutrients, gas exchange and heat, that were beneficial for soil microorganisms. Therefore, the populations of bacteria, fungi, actinomycetes and cellulose decomposition intensity in the upper soil layer $(0-10 \mathrm{~cm}$ depth) of the 'no-tillage + returning straw' treatment were the highest among four tillage and residue management systems. However, the cultivation method of 'tillage + returning straw' had a highest soil microbial communities in deep soil layer because it incorporated the straw input into the deeper soil layer $(10-20 \mathrm{~cm}$ depth) and promoted soil microbial growth and activity.

Soil quality is a concept that generally refers to the soil's ability to sustain productivity, environmental quality, human and animal health (Doran and Parkin, 1994). Therefore, analysis of soil quality should consist of a minimum data set that includes measures of soil physical, chemical, and biological properties (Papendick et al., 1994). Soil microorganisms are important for maintaining soil quality due to their role in decomposition of organic matter and nutrient cycling and storage, and potentially represent a very sensitive biological marker (Turco et al., 1994). Morris and Boerner (1999) suggested that the spatial distributions of soil microorganisms and the factors affecting them should be further investigated since both soil chemistry and vegetation are affected by soil microbial communities. Different tillage systems have significantly effect on soil microorganism (Gao et al., 2004; Balesdent et al., 1990; Wei et al., 1993). Ridge no-tillage was advantageous to improve soil ecological environment and soil fertility in paddy field (Fan and Liu, 2002).

The straw return significantly improved soil structure and increased soil nutrient concentration (Fan and Liu, 2002), and increased soil organic matter and available N, P, and K (Luo and Zhang, 1999), furthermore, the straw's cellulose, hemicelluloses, lignin and other components were decomposed slowly to release nutrients in the field with no-tillage condition, so there was a higher soil fertility later in the rice growth period. In the upper soil layer, the organic matter content for 'no-tillage + returning straw' treatment was 5.33, 2.79 and $5.37 \mathrm{~g} \mathrm{~kg}^{-1}$ higher than that for 'no-tillage', 'tillage + returning straw' and 'tillage' 
treatment, respectively. Also, the concentration of total and available $\mathrm{N}, \mathrm{P}$ and $\mathrm{K}$ were greatest in the 'no-tillage + returning straw' treatment, followed by the 'no-tillage' treatment and 'tillage + returning straw' treatment, and the lowest concentrations were in the 'tillage' treatment. In the deep layer, the fertility indicators for 'tillage + returning straw' treatment were higher than those for other treatments. The populations of bacteria, actinomycetes and cellulose decomposition intensity were significantly and positively correlated with the soil fertility indicators, which indicated that soil bacteria and actinomycetes were especially important for improving soil nutrient availability. The method of broadcast-transplanting seedlings in the field with high standing-stubble under no-tillage condition increased soil nutrient concentrations and soil microbial communities, and delayed senescence of root and shoots in the later growth stage (Xiao et al., 2009), and prolonged the grain-filling time, therefore, the spikelets of per ear, seed-setting rate, and 1 000-grains weight were increased, in comparison with conventional tillage and broadcasting seedlings. The findings provide insight into the physiological and ecological mechanisms whereby stable and high yield of broadcast-transplanted rice can be achieved in paddy field with high standing-stubble under no-tillage condition.

\section{Acknowledgements}

This study was supports by Chinese Ministry of Science and Technology (2004BA520A05; 2006BAD02A05; 2011BAD16B05).

\section{References}

[1] Xia J Y. Development and countermeasure about no-tillage cast-transplanted technology of high quality rice. China Agricultura Technology Extension, 2003, (6): 9-11 (in Chinese)

[2] Liu J, Huang H, Fu H, et al. Physiological mechanism of high and stable yield of notillage cast-transplanted rice. Sci Agric Sin, 2002, 35: 152-156 (in Chinese)

[3] Yang W Y, Ren W J. The new technology of broadcasting in the field with high standingstubbles under no-tillage condition. Sichuan Agricultural Sciences and Technology, 2000, (4): 13-14 (in Chinese)

[4] Liu D Y. The results and experience about extension of no-tillage cast-transplanted rice in Sichuan province. China Rice, 2006, (1): $54-55$ (in Chinese)

[5] Ren W J, Liu D Y, WU J X, et al. Effect of broadcasting rice seedlings in the field with high standing-stubbles under no-tillage condition on yield and some physiological characteristics. Acta Agronomica Sinica, 2008, 34(11): 1994-2002 (in Chinese)

[6] Peiris M E. Broadseedling- a promising new technique in paddy cultivation. Trop Agriculrist, 1956, 112: 105-108

[7] Zhang H C, Dai Q G, Zhong M X, et al. Studies on the yield formation and ecological characters of scattered-planting rice. Sci Agric Sin, 1993, 26(3): 39-49 (in Chinese) 
[8] Jiang L G, Li R P, Wei S Q, et al. Root growth and stanging characteristics of Jinyou253 seedlings under no-tillage with cast transplantation. J Guangxi Agric Biol Sci, 2005, 24(1): 30-34 (in Chinese)

[9] Liu J Z, Li Y K. Studies on the no-tillage and seedling-throwing culture in hybrid rice. Hybrid rice, 1999, 14(3): 33-34 (in Chinese)

[10] Ren W J, Yang W Y, Liu D Y, et al. The technology of broadcasting in the field with high standing-stubbles under no-tillage condition. China Rice, 2003, (2): 22-23 (in Chinese)

[11] Ren W J, Yang W Y, Fan G Q, et al. Effect of different tillage and transplanting methods on soil fertility and root growth of rice. J Soil Water Conserv, 2007, 21: 108-110,162 (in Chinese)

[12] Lu R-K. Analytical Methods of Soil and Agro-Chemistry. Beijing: China Agricultural Science and Technology Press, 2000 (in Chinese)

[13] Department of Microbiology, Institute of Soil Science, Chinese Academy of Sciences. Analytical Methods of Soil Microbe. Beijing: Science Press, 1985 (in Chinese)

[14] Zhu Q S, Wang Z Q, Zhang Z J, et al. Study on indicators of grain-filling of rice. J Jiangsu Agric coll, 1995, 16(2): 1-4 (in Chinese)

[15] Doran J W, Parkin T B. Defining and assessing soil quality. In: Doran J W, Coleman D C, Bezdicek D F and Stewart B A ed. Defining Soil Quality for a Substainable Environment. Madison, W I, USA: SSSA Special Publication Number 35, 1994, 321

[16] Papendick R.I., Parr J.F., and J. van Schilfgaarde. Soil quality: New perspectives for a sustainable agriculture. In Proceedings for International SoilConservation Organization. New Delhi, India, December 4-8, 1994

[17] Turco R.F., Kennedy A.C., Jawson M.D. Microbial indicators of soil quality. In J.W. Doranet al. (ed.) Defining soil qualityfor a sustainable environment. SSSA Spec. Publ. 35. SSSA, Madison, WI. 1994, 73-90

[18] Morris S.J., and Boerner R.E.J. Spatial distribution of fungal and bacterial biomass in southern Ohio hardwood forest soils: Scale dependency and landscape patterns. SoilBiol. Biochem. 1999, 31:887-902

[19] Gao M , Zhou B-T, Wei C-F , et al. Effect of tillage system on soil animal, microorganism and enzyme activity in paddy field. Chinese Journal of Applied Ecology, 2004, 15(7): 1177-1181 (in Chinese)

[20] Balesdent J, Mariotti A, Boisgontier D. Effect of tillage on soil organic carbon mineralization estimated from abundance in maize fields. Soil Science, 1990, 41: 587896

[21] Wei C-F, Gao M, Che F-C, et al. A study on infiltrated-ridged paddy soil ecosystem. Chinese Journal of Ecology, 1993, 12(3): 26-30 (in Chinese)

[22] Fan J-H, Liu M. Effect of different utilization methods on microorganism and its activation. Journal of tarim universivty of abricultural reclamation, 2002, 4(1): 15-17 (in Chinese) 
[23] Luo A-C, Zhang Y-S. Effect of organic manure on the numbers of microbes and enzyme activity in rice rhizosphere. Plant nutrition and fertilizer science, 1999, 5(4): 321-327 (in Chinese)

[24] Xiao Q-Y, Ren W-J, Yang W-Y, et al. Effect of cultivation method of broadcasting rice seedlings in the field with standing-stubbles under no-tillage condition on senescence characteristics of leaves during late stages of rice development. Acta Agronomica Sinica, 2009, 35(8): 1562-1567 (in Chinese) 


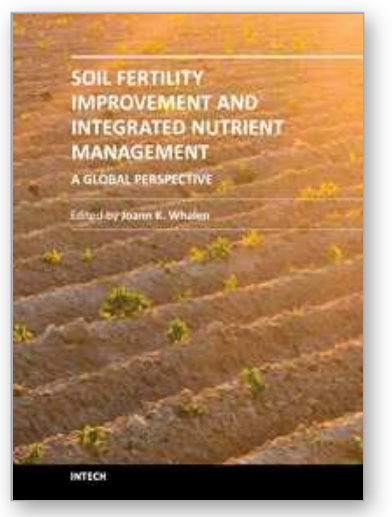

\section{Soil Fertility Improvement and Integrated Nutrient Management - A Global Perspective}

Edited by Dr. Joann Whalen

ISBN 978-953-307-945-5

Hard cover, 306 pages

Publisher InTech

Published online 24, February, 2012

Published in print edition February, 2012

Soil Fertility Improvement and Integrated Nutrient Management: A Global Perspective presents 15 invited chapters written by leading soil fertility experts. The book is organized around three themes. The first theme is Soil Mapping and Soil Fertility Testing, describing spatial heterogeneity in soil nutrients within natural and managed ecosystems, as well as up-to-date soil testing methods and information on how soil fertility indicators respond to agricultural practices. The second theme, Organic and Inorganic Amendments for Soil Fertility Improvement, describes fertilizing materials that provide important amounts of essential nutrients for plants.The third theme, Integrated Nutrient Management Planning: Case Studies From Central Europe, South America, and Africa, highlights the principles of integrated nutrient management. Additionally, it gives case studies explaining how this approach has been implemented successfully across large geographic regions, and at local scales, to improve the productivity of staple crops and forages.

\section{How to reference}

In order to correctly reference this scholarly work, feel free to copy and paste the following:

Ren Wan-Jun, Huang Yun and Yang Wen-Yu (2012). Effects on Soil Fertility and Microbial Populations of Broadcast-Transplanting Rice Seedlings in High Standing-Stubble Under No-Tillage in Paddy Fields, Soil Fertility Improvement and Integrated Nutrient Management - A Global Perspective, Dr. Joann Whalen (Ed.), ISBN: 978-953-307-945-5, InTech, Available from: http://www.intechopen.com/books/soil-fertility-improvementand-integrated-nutrient-management-a-global-perspective/effects-on-soil-fertility-and-microbial-populations-ofbroadcast-transplanting-rice-seedlings-in-hig

\section{INTECH}

open science | open minds

\section{InTech Europe}

University Campus STeP Ri

Slavka Krautzeka 83/A

51000 Rijeka, Croatia

Phone: +385 (51) 770447

Fax: +385 (51) 686166

www.intechopen.com

\section{InTech China}

Unit 405, Office Block, Hotel Equatorial Shanghai

No.65, Yan An Road (West), Shanghai, 200040, China 中国上海市延安西路65号上海国际贵都大饭店办公楼 405 单元

Phone: +86-21-62489820

Fax: +86-21-62489821 
(C) 2012 The Author(s). Licensee IntechOpen. This is an open access article distributed under the terms of the Creative Commons Attribution 3.0 License, which permits unrestricted use, distribution, and reproduction in any medium, provided the original work is properly cited. 